\title{
Seed production issues that limit supplies or result in high market prices of dryland legume species
}

\author{
M.P. ROLSTON \\ AgResearch Ltd, PO Box 60, Lincoln \\ phil.rolston@agresearch.co.nz
}

\begin{abstract}
A barrier to the adoption of many dryland legumes by grassland farmers is the lack of supply and/or the high price of seed. Growers face a number of problems in growing dryland legumes for seed, including a high risk of crop failure; alternatives such as wheat, barley and perennial ryegrass seed are lower risk crops. Gross margins for legume seed crops (including white clover) indicate that they have low profitability, at present prices if yields are average. Pollination remains a serious limitation to production, especially for dryland crops that are not well pollinated by honeybees. Both internationally and in New Zealand there has been a major decline in seed production research in the last decade, and little new research has been published on seed production of a range of dryland legumes. Seed production issues limiting yield in a range of dryland seed crops in New Zealand are identified. The paper concludes with suggestions that may help overcome some of these limitations.
\end{abstract}

Key words: economics, lucerne, production constraints, red clover, white clover

\section{Production trend}

White clover (Trifolium repens) dominates legume seed production in New Zealand (NZ), representing more than $90 \%$ of all forage legume seed for the period 1990 to 2000 (Table 1). Seed production of all forage legume crops is declining in NZ. White clover seed production peaked at 6110 metric tonnes (T) in 1992, but has averaged $3630 \mathrm{~T}$ for the three years 19982001. This average does not include the very low 2001/02 harvest year when wet weather resulted in a crop of only $855 \mathrm{~T}$ (Figure 1). Red clover (T. pratense) production has also dropped 50\% from a peak in 1988 (Figure 1), while lucerne (Medicago sativa) and lotus (Lotus uliginous and L. corniculatus) seed production are more than $90 \%$ less than 1990 production (Figure 1). Production of other legume species that occurred in the 1990s, including serradella (Ornithopus sativa and O. sativa $x$ O. compressus), strawberry clover (T. fragiferum), sulla (Hedysarum coronarium), vetch (Vicia sativa and $V$. benghalensis), and Caucasian clover (T. ambiguum) has either stopped or been reduced to a few hectares.

Although agronomic problems have occurred in production of all these species (perhaps with the exception of white clover) a combination of high seed prices and low seed yields has limited the demand for dryland legume seeds.

Table 1 Comparison of New Zealand volume and percentage seed production of legume by species in 1990 and 2000 .

\begin{tabular}{lcccc}
\hline & \multicolumn{2}{c}{1990} & \multicolumn{2}{c}{2000} \\
\hline & Tonne & $\%$ & Tonne & $\%$ \\
\hline White & 4183 & 92.3 & 3246 & 93.1 \\
Red & 192 & 4.2 & 232 & 6.7 \\
Lucerne & 59 & 1.3 & 4 & 0.1 \\
Lotus & 98 & 2.2 & 6 & 0.2 \\
Caucasian & 0 & 0.0 & 12 & 0.3 \\
Others & 0 & 0.0 & 0 & 0.0 \\
\hline Total & 4532 & & 3500 & \\
\hline
\end{tabular}

Source AgriQuality NZ, Seed Certification Statistics 1990, 2002.

\section{Factors linked to seed price}

\section{Economic issues.}

High priced seed is limiting the uptake of many dryland legumes. For example there is a potential market for birdsfoot trefoil seed if it were retailing at less than $\$ 10 / \mathrm{kg}$, but the current price of NZ-grown seed is close to $\$ 20 / \mathrm{kg}$ (B. Belgrave, pers. comm.). Contract grower seed prices are often based on achieving a per hectare gross margin that is comparable with wheat crops. Average seed yields of many legume seed crops are low (Table 2), and high grower prices are required to attract growers. Wheat gross returns are $\$ 2250$ to $\$ 2500 /$ ha. Legume seed crops cost $\$ 1000$ to $\$ 1200 /$ ha to grow, with additional costs of crop desiccation, seed cleaning 


\section{White clover}

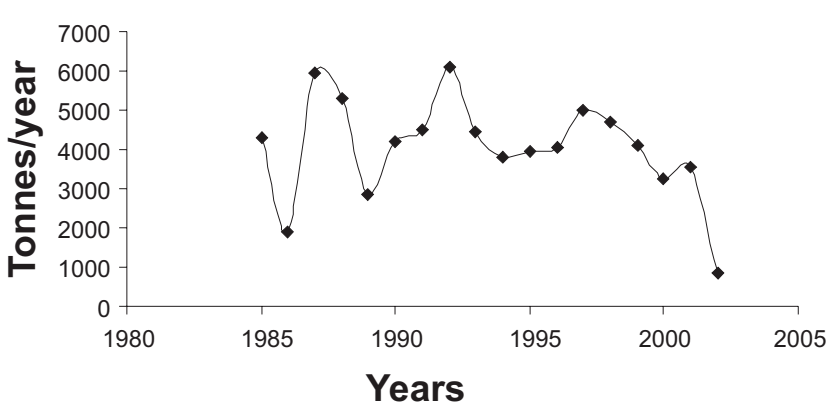

Red clover

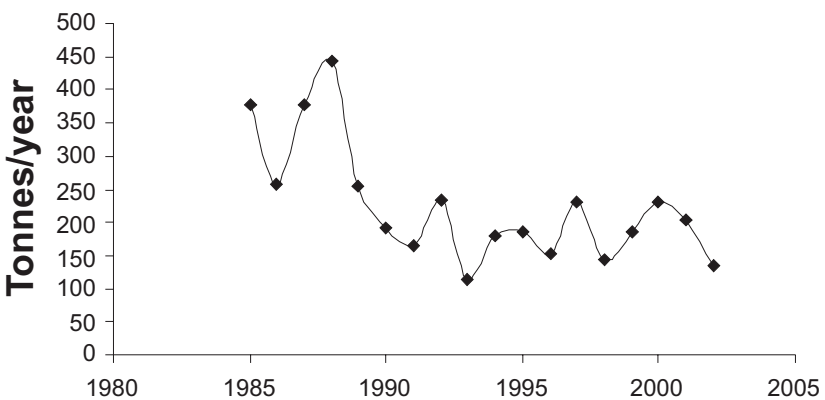

\section{Lucerne}

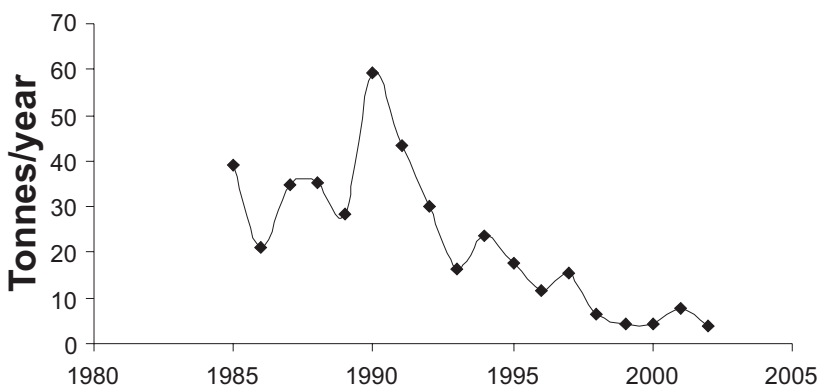

\section{Lotus}

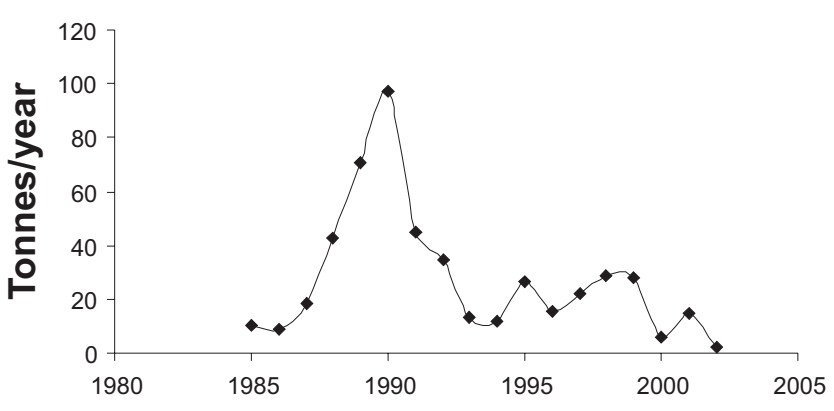

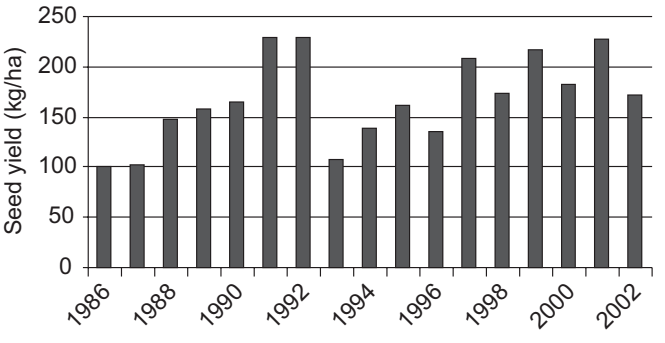

Figure 2 Annual average seed yield ( $\mathrm{kg} / \mathrm{ha}$ ) for red clover in New Zealand from 1986 to 2002 (derived from Seed Certification statistics, AgriQuality NZ).

and certification that wheat growers do not face. If legume seed crops do not achieve a gross revenue of \$2 500/ha (seed \$2 $000+$ grazing/hay $\$ 500 /$ ha), it is unlikely that the crop will provide an adequate return. Average yielding crops of most legumes currently have a gross return of $\$ 1000$ to $\$ 1700 /$ ha (Table 2). At present prices, average grower yields (or prices) need to increase by between 13 and $30 \%$ (and more for Caucasian clover) to achieve gross returns of $\$ 2500 /$ ha (Table 2). Several seed companies have commented that in 2003 they struggled to find enough growers to meet contract area for legume seed crops and have begun looking offshore for alternative production sites.

Although pure pasture legume stands can fix substantial amounts of nitrogen (Brock 1973) and grain legumes can enhance the dry matter yield of Italian ryegrass in a rotation (Ganeshan et al. 1998), farmers and their economic advisers rarely place a value on this component.

Retail prices are typically double the grower price. Costs from farmer payment to the market include royalties, storage, interest on seed payments, administration, staff, office costs and rental, transport, wholesaler and retailer margins, demonstrations, marketing and

Figure 1 Annual NZ seed production 1985 - 2002 of white and red clover, lucerne and lotus (lotus and birdsfoot trefoil) from Seed Certification Statistics, AgriQuality NZ. 
Table 3 Average seed yields for pasture legumes based on Seed Certification Statistics (AgriQuality NZ) and best farmer seed yield known to the author.

\begin{tabular}{lccc}
\hline Species & $\begin{array}{c}\text { Seed yield } \\
(\mathrm{kg} / \mathrm{ha})\end{array}$ & $\begin{array}{c}\text { Best farmer } \\
\text { yield (kg/ha) }\end{array}$ & Source \\
\hline White clover & 308 & 1150 & Agricom NZ Ltd \\
Birdsfoot trefoil & 106 & 800 & \\
Lotus & 111 & 500 & \\
Caucasian clover & 95 & 500 & K. Widdup, pers. comm. \\
Lucerne & 208 & 500 & \\
$\begin{array}{l}\text { Red clover } \\
\text { (2N \& 4N) }\end{array}$ & 177 & 1100 & $\begin{array}{c}\text { G. Sparks, pers. } \\
\text { comm. }\end{array}$ \\
Sulla & $150-500$ & 1000 & $\begin{array}{c}\text { Foote \& Douglas } \\
(1998)\end{array}$ \\
Serradella & - & 2600 & $\begin{array}{c}\text { Rolston \& Foote } \\
\text { (1998) }\end{array}$ \\
\hline
\end{tabular}

advertising costs. Some of these costs are fixed, but marketing costs $/ \mathrm{kg}$ decline as seed volumes increase. Legume seed crops (with the exception of white clover) are small volume and have large post farmgate unit costs.

For companies to have a profitable business from a

Table 2 Average yield (1990-2002), grower price and gross return per ha, and estimated yield and/or price required to achieve a $\$ 2500 /$ ha gross return from pasture legume seed production based on current price and average yield.

\begin{tabular}{lccccc}
\hline & $\begin{array}{c}\text { Avg. yield } \\
(\mathrm{kg} . \mathrm{ha})\end{array}$ & $\begin{array}{c}\text { Price }^{1} \\
\text { paid } \\
(\$ / \mathrm{kg})\end{array}$ & $\begin{array}{c}\text { Gross }^{1} \\
\text { return } \\
(\$ / \mathrm{ha})\end{array}$ & $\begin{array}{c}\text { Yield }^{2} \\
\text { required } \\
(\mathrm{kg} / \mathrm{ha})\end{array}$ & $\begin{array}{c}\text { Price }^{3} \\
\text { required } \\
(\$ / \mathrm{kg})\end{array}$ \\
\hline White & 308 & 5.25 & 1617 & 381 & 6.49 \\
Red (diploid) & 257 & 6.50 & 1670 & 308 & 7.78 \\
Lucerne & 208 & 8.50 & 1768 & 235 & 9.62 \\
Lotus & 111 & 14.00 & 1554 & 143 & 18.02 \\
Caucasian & 96 & 10.50 & 1008 & 190 & 21.05 \\
\hline
\end{tabular}

${ }^{1}$ Price paid to growers for the 2002/03 season.

${ }^{2}$ Yield required to achieve a gross return of $\$ 2500 /$ ha ( $\$ 2000$ for seed and $\$ 500$ for grazing) based on $2002 / 03$ prices.

${ }^{3}$ Price required by grower to achieve $\$ 2500 /$ ha return ( $\$ 2000$ for seed and $\$ 500$ for grazing) with average yield. new proprietary legume cultivar, a market size of $20 \mathrm{~T}$ is required (B. Belgrave, pers. comm.). Small volume species do not fit the business of larger seed companies. For minor species, new ways of bringing seed producers and niche end-users together must be found if these species are to play a role in NZ pastures.

\section{Risks of growing legume seed crops}

The seed yields of most herbage crops are more susceptible to adverse weather than cereals, especially to the impact of above average summer rain. Legume seed crops have a high risk of failure in wet summers, as happened in the 2001/02 harvest year. Many white clover growers failed to harvest any seed, and the total production was only 855 $\mathrm{T}, 76 \%$ less than on average of the previous 3 years. Year to year variation in red clover seed yield (Figure 2) is typical of the problems growers of legume seed crops incur, and annual variations in seed yield for individual growers are thought to be wider. Common financial advice by farm consultants to arable/herbage seed growers is a strong recommendation on risk aversion, including advice to avoid growing risky legume crops.

\section{Specialist equipment}

Specialist alternative legume growers often have small, old combines with adjustable rasp bars and backing plates. New combines with wide pick-up fronts and faster ground speeds are designed for cereals and are often not as efficient in extracting seeds from legumes. Smaller producers who specialised in alternative legumes often exit the industry when their old machinery needs to be replaced.

\section{International production}

The costs of growing birdsfoot trefoil, lucerne and red clover, particularly in Canada, the USA and Argentina, are lower than in NZ, through either higher yields or lower land and cost structures. Lucerne seed yields in the warm regions of western USA (Idaho, California) are higher than in NZ. Australia generally has lower land costs in the southern legume growing area (South Australia, 
$(161-168)$

Table 4 Production problems and possible solutions for different dryland legume species.

\begin{tabular}{|c|c|}
\hline Problem & Solutions/Research options \\
\hline \multicolumn{2}{|l|}{ Birdsfoot trefoil and Lotus } \\
\hline Pod shattering at high temperatures and low humidity & Potential role for "pod-softening agents"; research required \\
\hline Excessive summer vegetative growth in wet years & $\begin{array}{l}\text { Role of plant growth regulators to reduce summer } \\
\text { vegetative growth, e.g. trinexapac-ethyl (Moddus) }\end{array}$ \\
\hline Poor pollination & Ensure that bee attractive crops are not grown near by \\
\hline White clover contamination and weeds & $\begin{array}{l}\text { Control with sulfonyl urea herbicides, chlorimuron or } \\
\text { thifensulfuron-methyl }\end{array}$ \\
\hline \multicolumn{2}{|l|}{ Caucasian clover } \\
\hline Achieving good establishment & $\begin{array}{l}\text { Good weed control and appropriate (early), time of } \\
\text { sowing }\end{array}$ \\
\hline $\begin{array}{l}\text { Preventing competition and contamination from } \\
\text { white clover }\end{array}$ & Use a suitable herbicide; e.g. hexazinone (Velpar) \\
\hline $\begin{array}{l}\text { Maintaining crown morphology with restricted } \\
\text { rhizome development }\end{array}$ & $\begin{array}{l}\text { Grow on heavy soils or use early spring application of } \\
\text { glyphosate herbicide }\end{array}$ \\
\hline \multicolumn{2}{|l|}{ Dorycnium } \\
\hline Wheel damage from machinery & $\begin{array}{l}\text { Use wider rows to avoid wheel damage, reduce tyre } \\
\text { pressure }\end{array}$ \\
\hline Poor plant survival after harvest & Use a higher cutting height \\
\hline Poor seed yields in "cool" environments & Production sited in "warm" environments \\
\hline $\begin{array}{l}\text { Extended flowering period makes predicting harvest } \\
\text { time difficult. }\end{array}$ & Requires research \\
\hline
\end{tabular}

Lucerne

Poor pollination with honeybees (Apis mellifera) in the cool conditions found in Canterbury

Site seed production in "warm environments" and use other pollinators

Leaf cutter bees (Megachile rotundata) require specialist management to maintain populations

Technical training and adequate financial returns for pollination services

(B. Donovan pers. comm.)

Osmia bees (Purves et al. 1998) not commercially available (B. Donovan pers comm.)

Research on management of bee parasites required

\section{Red clover}

Poor pollination of both diploid and tetraploid cultivars due to low numbers of both short and long tongue bumble bee (Bombus sp.) populations

Shortage of artificially raised and/or captured bumblebees

Floral competition from bee attractive crops (e.g. borage and white clover) reduces effectiveness of honeybees

Excessive summer vegetative growth in wet years

Over-watering with irrigation
Grow in areas with good bumblebee populations; introduce artificially raised and/or captured bumblebees

Cost effectiveness of introducing bumblebees must be evaluated

Improved planning of crop rotations and inter-neighbour co-operation

Research role of trinexapac-ethyl to reduce growth

Monitoring soil water with probes 
Subterranean clover

Harvesting limitations and vacuum harvesters not available

Not price competitive with Australian produced seed

Sulla

De-hulling of seed

Few herbicide options available for broadleaf weed control

Tasmania, Victoria and Western Australia) and therefore a lower unit cost structure.

\section{Alternative land use}

Significant changes in land use, especially with the expansion of grape production in Marlborough and dairying and potato production in Canterbury, have resulted in the loss of land traditionally used for legume seed production. Marlborough was the traditional production area for red clover and lucerne, due to high populations of bumblebees (Bombus sp.) and weather that favours bee pollination: warmer summers and little wind. Most other regions, especially Canterbury, are too windy and cool in the summer for successful pollination of lucerne. The higher value of arable land in districts where grapes
New harvesting approach, inducing aboveground seeding by heavy rolling to produce compact soil surface (P. Clifford, pers. comm.)

Grow new cultivars in Australia
Experimental equipment developed by NZAgriculture Engineering Institute (now Lincoln Ventures), or de-hulling with a Forsberg huller/scarifier (L. Foote, pers. comm.)

Weed control research required

$\begin{aligned} \text { Table } 5 & \begin{array}{l}\text { Relationship between pasture legume seed production (percent production) and percent and } \\ \text { number of publications (1970-2002) for New Zealand in research journals and conference }\end{array}\end{aligned}$

$\begin{aligned} & \text { Table } 5 \text { Relationship between pasture legume seed production (percent production) and percent and } \\ & \text { number of publications (1970-2002) for New Zealand in research journals and conference }\end{aligned}$ proceedings.

\begin{tabular}{lcccccc}
\hline \multicolumn{7}{c}{ No. of publications } \\
\hline Species & \% production & $\%$ of publications & Total & $1970-1984$ & $1985-1994$ & $1995-2002$ \\
\hline White & 92.3 & 38 & 28 & 6 & 18 & 4 \\
Lotus & 2.3 & 24 & 18 & 1 & 15 & 2 \\
Lucerne & 1.4 & 11 & 8 & 8 & 0 & 0 \\
Red & 4.0 & 8 & 6 & 5 & 1 & 0 \\
Caucasian & 0 & 8 & 6 & 0 & 1 & 5 \\
Sub & 0 & 3 & 2 & 0 & 0 & 2 \\
Vetch & 0 & 3 & 2 & 0 & 0 & 2 \\
Sulla & 0 & 1 & 1 & 0 & 1 & 1 \\
General & - & 4 & 3 & 2 & 36 & 0 \\
\hline Total & 100 & 100 & 74 & 22 & 0 \\
\hline
\end{tabular}

and dairy are alternative land uses has increased the financial pressure on seed producers to grow other low risk crops that provide a consistent income. This has contributed to the decline in legume seed production.

\section{Factors linked to low yields}

\section{Paddock size and pollination}

During the last 5 years there has been an acceleration in the trend towards larger arable farms to achieve economies of scale. Associated with this is the creation of new farm layouts to accommodate land acquisitions, larger irrigation systems (centre pivots and mobile laterals) and farm equipment, and larger paddocks, often $20-30$ ha in area. As part of this 
process shelter belts and hedgerows are often removed, resulting in fewer bumblebee nesting sites and the shelter needed for honey bee activity. Average paddock size on traditional farms has increased to $7-10$ ha, compared with $<5$ ha a decade ago. Bigger paddocks result in a dilution of natural pollinators, and in red clover, seed yields are inversely related to paddock size (Clifford \& Anderson 1980). Apiarists set up colonies in spatial patterns that are easy to service, and probably maximise honey production per hive, but crop observations suggest that many hive placements are not optimum for effective pollination. Hives are often clustered at one end of a field, increasing the chance of bees being attracted to neighbouring crops.

\section{Species limitation and possible solutions}

High seed yields are occasionally obtained for most legume species, both in research and commercial crops, but average yields remain low (Table 3). Average yields (calculated from AgriQuality NZ annual production statistics) have increased steadily over the last 15 years, with annual increases for lucerne, red and white clover at12.0, 4.3 and $5.4 \mathrm{~kg} /$ $\mathrm{ha} /$ year respectively. These increases in per ha yields can be attributed to a combination of less efficient growers leaving the industry and the adoption of new crop management practices (e.g. direct heading and wider row spacing in white clover).

There are numerous agronomic and physiological issues in seed production that must be considered when new species are introduced into the market. For individual species, some of the seed production limitations and possible technology solutions are noted in Table 4.

\section{Research input to provide solutions}

Many alternative legume seed production problems may have solutions that can be resolved by research. However, the current research structures in New Zealand are unlikely to deliver the funds required for research on alternative legume agronomy and seed production. Research on legume seed production and pollinators has declined over the last 5 years both internationally and nationally. Publications on NZ legume seed production research in journals and conference proceedings reached a peak during 1985 1995, and have declined since then (Table 5). The publications show a significant amount of work on alternative species (61\% of all publications). In contrast, $39 \%$ of the publications were on white clover, while production of this species was $92 \%$ of all legume seed grown (Table 5). The decline in publications from 1995 is associated with the total loss of "public-good" government funding for legume seed production research from the Foundation for Research, Science and Technology (FRST). Reduced funding has resulted in a decline of AgResearch science personnel involved in legume seed production research from 2.5 full time equivalents (FTE) in the 1985-1990 period, to 0.3 FTE in 2003.

Since 1994, grower-funded seed research has occurred through the establishment of the Foundation for Arable Research (FAR). However, present research is focused on white clover. Although FAR has been prepared to fund some work on alternative legumes, its funds are based on seed grower levies. Thus, FAR attempts to maintain a balance between source of funds (white clover representing about $90 \%$ of the forage legume revenue) and the potential of alternative legumes to impact on future grower revenues.

Historically, NZ universities have also undertaken seed production research, but the reduction in both $\mathrm{NZ}$ and overseas students undertaking postgraduate studies means fewer studies related to forage legumes are undertaken. Two seed companies (Pyne Gould Guinness and Wrightson) undertake seed production research trials on legumes; however the results are generally kept "in-house" for company field representatives and grower clients.

\section{Farmer experimentation.}

With any new crop, farmer experimentation is an important component in the development of new information (e.g. a Caucasian clover grower achieved high yields after he sprayed the crop with glyphosate at $1.0 \mathrm{~kg}$ ai/ha to control a range of difficult to control weeds). Meetings where growers share information, facilitated by researchers, can be a powerful tool in finding solutions, as demonstrated with white clover and other crops (Rowarth et al. 1993) and in ryegrass (Rolston \& McCloy 1997).

\section{The future}

If seed production of the present mainstream legumes (white and red clover, lucerne and lotus) is already in decline, how will alternative legumes fare? The present research and development structure, and trends in the arable/herbage seed industry suggest that NZ-based production using the existing seed 
production infrastructure will not solve the problems of poor supply and/or high cost of alternative legume seeds. However, legumes do have a role to play as break crops for disease and weed management. Thus, they can be expected to have at least a small role in crop rotations. New structures for the production and marketing of niche legume species are required (e.g. seed growers linked directly to consumers) and production must be focused in regions that have a good track record for production of the particular species. Alternatively, production could be moved offshore to sites with more suitable environments, production experience of the species, and lower cost structures than New Zealand.

\section{REFERENCES}

AgriQuality NZ. 1991. Seed Certification Statistics 1990-1991.

AgriQuality NZ. 2001. Seed Certification Statistics 2000-2001.

AgriQuality NZ. 2003. Seed Certification Statistics 2002-2003.

Brock, J.L. 1973. Growth and nitrogen fixation of pure stands of three pasture legumes with high/low phosphate. New Zealand Journal of Agriculture Research 16: 483-491.

Clifford, P.T.P.; Anderson, A.C. 1980. Red clover seed production-research and practice. pp. 76-79. In: Ed. J.A. Lancashire, Herbage Seed Production., Grassland Research and Practice Series No. 1.

Foote, A.G.; Douglas, G.B. 1998. Sulla. pp. 157-161. In: Practical Herbage Seed Crop Management. Ed. J. Rowarth, Lincoln University Press, Lincoln, New Zealand.

Ganeshan, V.; Hill, G.D.; McKenzie, B.A. 1998. The dry matter yield of Italian ryegrass grown after grain legumes in a crop rotation. Proceedings of the Agronomy Society of New Zealand 28: 87-94.

Purves, R.G.; Clifford, P.T.P.; Donovan, B.J. 1998. Preliminary observations of Osmia coerulescens as a pollinator of herbage seed crops. Proceedings New Zealand Grasslands Association 60: 161164.

Rolston, M.P.; McCloy, B.L. 1997. Ryegrass 2000: technology transfer in ryegrass seed production. Proceedings of the Agronomy Society of New Zealand 27: 5-8.

Rolston, M.P.; Foote, A.G. 1998. Serradella. pp. 153156. In: Ed. J. Rowarth, Practical Herbage Seed Crop Management. Ed.. Lincoln University Press, Lincoln, New Zealand.

Rowarth, J.S.; Clifford, P.T.P., Archie, W.J.; Guy, B.R. 1993. Technology transfer and the seed industry: a success story. Proceedings of the Agronomy Society of New Zealand 23: 113-115. 
